

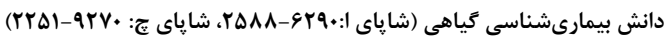

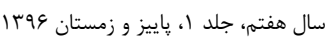

Plant Pathology Science (eISSN:2588-6290, pISSN:2251-9270) Vol. 7(1), 2018

\title{
Olive Quick Decline Syndrome Disease
}

\section{MANSUREH KESHAVARZI ${ }^{凶}$}

Institute of Horticultural Science Research, Cold and Temperate Fruits Center, Agricultural Research, Education and Extension Organization, Karaj, Iran

(凹:kmansureh@gmail.com)

Received: 30.01 .2017

Accepted: 28.08.2017

Keshavarzi M. 2018. Olive quick decline syndrome disease. Plant Pathology Science 7(1):40-50.

Abstract : Quick Decline Syndrome of Olive caused by Xylella fastidiosa subsp. pauca, is currently spread in some European countries in Mediterranean Sea area and there is a risk of its spread beyond the Middle East. The initial symptom is marginal leaf blight, then fruit drop and shoot dieback appears. Growing multiple suckers and finally death of whole tree are the other symptoms. In addition to olive, almond and oleander are also susceptible to this pathogen. The characteristics, biology, host range, transmission and distribution routes of the causal agent are described. In addition, disease prevention and management methods are proposed here.

Key words: Decline, Olive, Xylella

$$
\begin{aligned}
& \text { بيمارى سندروم زوال سريع زيتون } \\
& \text { منصوره كشاورزى } \\
& \text { يزوهشكده ميوههاى معتدله و سردسيرى، موسسه تحقيقات علوم باغبانى، منوره }
\end{aligned}
$$

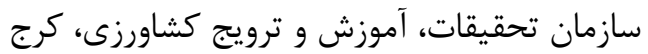

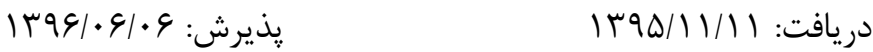

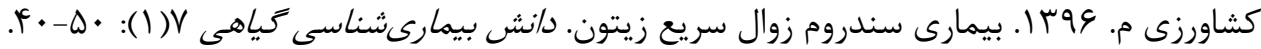

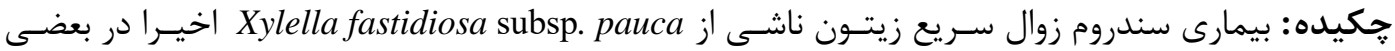
كشورهاى ارويايى در حوزه درياى مديترانه شيوع يافته است و خطر انتشار آن به كشورهاى خاورميانـهـ وجـود

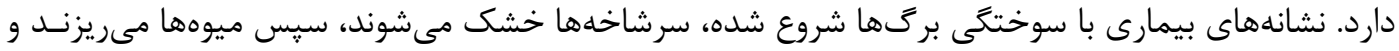

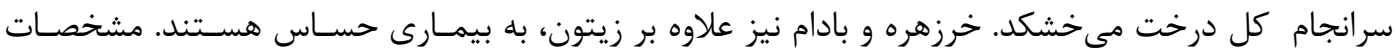

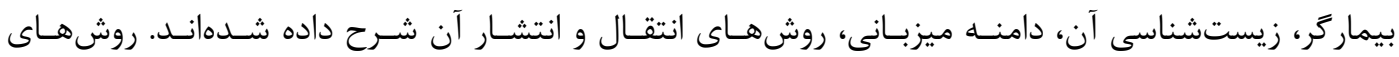


وازههاى كليدى: زوال، زيتون، Xylella

مقدمه

"سندروم زوال سريع زيتون" با عامل(Sylella fastidiosa subsp. pauca (Schaad et al. 2004)

مهلكترين بيمارىهاى زيتون است كه به مرى قطعى درختان منتهى مىشود (Giampetruzzi et al. 2015). 
اين بيمارى براى اولين بار در سال r| · ميلادى در ايتاليا مشاهده و بهسرعت در باغهاى زيتون جنوب و شمال اين كشور در حال گسترش است (Saponari et al. 2013) بيمارى فوق در ليست بيمارىهاى قرنطينهاى درجه اول ارويا قرار دارد و بهدليل خسارت بالا و نبود سم مؤثر عليه آن، برخى كشورهاى ارويايى و ايالات متحده آمريكا آن را در ليست عوامل خطرناك قرنطينهاى قرار دادهاند. شرايط آب و هوايى منطقه خاورميانه از جمله تركيه و ايران نيز براى استقرار و گسترش آن بسيار مساعد است و هرگونه بىدقتى در واردات، ممكن است منجر به ورود اين بيمارى به كشور شود. در اين نوشتار ابتدا بيمارىهاى مختلف ناشى از باكترى (Welles et al. 1987) و و راههاى مديريت آنها و سيس سندروم زوال سريع زيتون شرح داده مىشوند.

\section{X. fastidiosa - Iامنه ميزبانى}

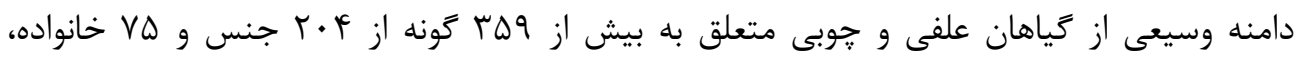

ميزبانان آن هستند. ميزبانان مهم اقتصادى آن شامل: دانهريزها (انگُور، بلوبرى، توتقرمز)، مركبات، آجيلى

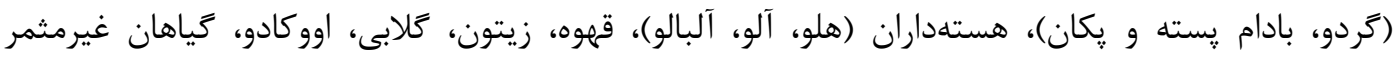
(خرزهره، نارون، بلوط، جنار و افرا) و يونجه هستند. بسيارى از علفهاى هرز باريك برك، جكن، تيره زنبق، بوتههاى وحشى و درختان جنگلى و غيرمثمر، نشانهاى بيمارى را نشان نمىدهند و ميزبان ينهان اين باكترى محسوب مىشوند. خسارتزاترين بيمارىهاى حاصله شامل يِيرس انكور (Pierce's disease)، فونى هلو (Phony peach)، سوختگى برى (Leaf scorch) (بادام، يُكان، توت، قهوه، خرزهره، بلوط و...)، جوش برى آلو (Plum leaf scald)، زردى ابلق مركبات (Citrus variegated chlorosis)، كوتولتى يونجه ( Alfalfa) (dwarf و سندرم زوال سريع زيتون (Olive quick decline syndrome) هستند(Hopkins 1989) .

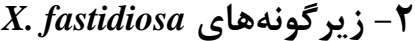

جهار زير گونه به شرح زير تاكنون تائيد شدهاند (Denance et al. 2017).


قهوه، سوختكى برك بادام، زردى ابلق مركبات و كوتولكى يونجه است. اين زيركونه در آمريكاى جنوبى و 
مركزى و تايوان گسترش دارد. بيمارى ييرس انگور اولين بار در سال 1199 در ايالات متحده كشف و اكنون در مناطق گستردهاى از جمله آمريكاى مركزى و جنوبى (مكزيك، كاستاريكا، ونزوئلا) انتشار دارد. Y fastidiosa subsp. multiplex (Schaad et al. 2009) دامنه ميزبانى آن بسيار وسيع است. عامل بيمارىهاى سوختكى برى در بادام، بلوط، نارون قرمز، زردآلو و برخى گياهان زينتى، جوش برگ آلو و فونى هلو است. نخستين بار در سال هـا ا در آرزانتين بهعنوان عامل جوش برگ آلو شناسايى شد. در قاره آمريكا (آمريكاى مركزى و جنوبى، ايالات متحده آمريكا) و در كياهان زينتى در فرانسه اهميت دارد. r-r. fastidiosa subsp. pauca (Schaad et al. 2004) عامل بيمارىهاى زردى ابلق مركبات و سوختخى برى (قهوه، گياهان زينتى) در آمريكا (آرزانتين، برزيل، كاستاريكا، ياراگوئه) و سندورم زوال سريع زيتون و سوختگى برگ بادام و خرزهره در ايتاليا است. آلودگى به آن در نهالهاى قهوه زينتى وارداتى به فرانسه، آلمان، هلند و ايتاليا نيز مشاهده شده است. r. fastidiosa subsp. sandyi (Schuenzel et al. 2005) - عامل سوختگى برگ خرزهره در ايالات متحده آمريكا است.

زيرگونهاى مختلف X. fastidiosa اختصاصى عمل مى كنند. سوشهاى بيماركر در انگور قادر به آلوده كردن هلو و سوشهاى بيماركر خرزهره قادر به آلوده كردن انكور نيستند و برعكس. سوشهاى بيمارگر مركبات و قهوه گر جه بهطور آزمايشى انگور را آلوده مى كنند، اما آلودگى طبيعى انگور به آنها ديده نشده است (Hopkins and Purcell 2002). در ايران، اخيراً اين باكترى از انكور (استانهاى جهارمحال و بختيارى، خراسان رضوى، قزوين، اصفهان، همدان، البرز) و بادام (جهارمحال و بختيارى، آذربايجان غربى و سمنان) كزارش شده است (Amanifar et al. 2014 ). ايران بعد از تايوان، دومين كشور آسيايى است كه اين باكترى ا اززارش مى كند.

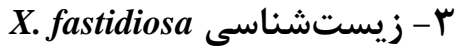

اين باكترى كرم منفى، ميلهاى شكل، هوازى اجبارى، بدون تازى و بسيار كندرشد است. قطر آن

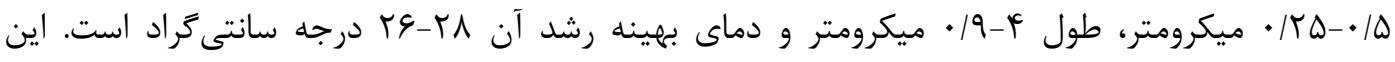
باكترى در آوند جوبى، ريشه، برى و شاخه زيست و تكثير مى كند و مىتواند به سمت بالا و پائين حركت كند 
(Janse and Obradovic 2010). حشرههاى ناقل كه عمدتاً از زنجر كها هستند، پِ از تغذيه از كَياه آلوده، بهطور مادامالعمر آلوده مىمانند و مىتوانند دائماً بيمارى را به كياه سالم منتقل كنند، از اين رو جرخه زندكى آن داراى يك مرحله در درون حشره ناقل و مرحلهاى در گياه ميزبان است (Severin 1949 ).

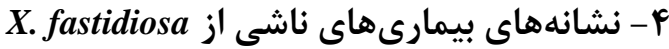

اين باكترى در آوند جوبى مستقر است. در اثر تراكم سلولهاى باكترى و توليد تيلوز، آوند جوبى مسدود و جريان شيره آوندى قطع يا كند مىشود و اكثر نشانها نيز مرتبط با همين توقف جريان شيره خام در آوند جوبى است، گرجه توليد زهرابه نيز در سوختكى حاشيه برگ نقش دارد. بسته به ميزبان و زيركونه باكترى، يك يا جند مورد از نشانههايى مانند سوختگى برگ قهوهاى شدن حاشيه برگ محاط با هاله زردرنگ، يزٔمردى و خشكيدن سرشاخه/شاخه، كوتولكى، ريزش زودهنگام برك، ريزى، بدشكلى يا موميايى شدن ميوه ايجاد مىشود كه منجر به كاهش كيفيت و كميت محصول مى گردد. اين در حالى است كه آلودگى به اين باكترى در ميزبانهايى جون زيتون (بيمارى سندرم سريع زوال زيتون) و مو (بيمارى پيرس مو)، به مرى درخت منتهى مىشود.

\section{F - محوه انتشار بيماركر}

ممهمترين راههاى انتشار از طريق حشرههاى ناقل و جابجايى قطعات كياهى ( قلمه و نهال) آلوده است. f-1- حشرههاى ناقل: حشرههاى تغذيهكننده از آوند جوبى مانند زنجركهاى سرخرطومى و زنجرههاى قورباغهاى (Sharpshooter) حشرههايى بسيار يراشتها هستند كه روزانه در دفعات متعدد، صدها برابر حجم بدنشان شيره آوندى مىمكند. آنها دو ساعت يس از اولين تغذيه آلوده، آلوده مىشوند و مادامالعمر آلوده و ناقل باقى مىمانند. جابجايى اين حشرهها در مسافتهاى كوتاه توسط يرواز (حدود . ․ متر) و به كمك باد (بيش از . ‥ متر) و در مسافات طولانى در سطح بينالمللى بر روى مواد گياهى و ميوه (به شكل تخم، يوره و حشره بالغ) انجام مىشود 


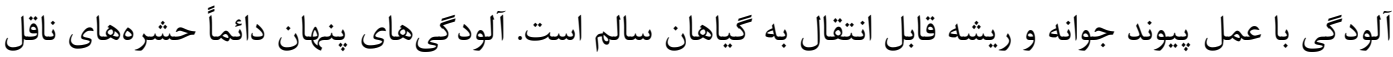
سالم را آلوده و بيمارى را گسترش مىدهند (Janse and Obradovic 2010).

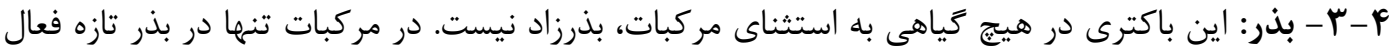
است و در بذر خشك شده از بين مىرود (Janse and Obradovic 2010).

\section{X. fastidiosa مديريت بيمارى هاى ناشى از}

راهكارهاى مديريتى به اين شرح هستند (Hopkins and Purcell 2002):

ه-1- قرنطينه: واردات مواد گياهى (نهال/اندام رويشى) از مناطق يا كشورهاى آلوده به مناطق گٍاى بايد ممنوع يا بسيار محدود شود. گياهان وارداتى بايد يس از بازرسى اوليه جشمى به قرنطينه منتقل شوند. در


بازرسى جشمى مىشوند كه معادل 99\% اطمينان از بازرسى 1\% محموله است، محمولههاى كوجى بلطور كامل بازرسى مىشوند و طول دوره قرنطينه براى گياهان با برجسب سلامت، دو سال است. گياهان وارداتى در مرحله خواب را بايد تا مرحله رشد رويشى در قرنطينه نكهدارى و سيس بازرسى جشمى انجام داد. سازمانهاى نظارتى بايد علاوه بر ميزبانان اصلى، ساير ميزبانان با آلودگىهاى ينهان را نيز بشناسند. همجنين مواد كياهى وارداتى بخصوص از كشورهاى آلوده بايد از حشره ناقل نيز عارى باشند. ممكن است تخم، يوره و بالغ حشره ناقل آلوده بر روى ميوه و مواد كياهى منتقل و وارد مناطق پاك شود. اندازه تخم بسيار ريز است و در مبادى بازرسى بهسختى تشخيص داده مىشود. يوره يس از يوستاندازى عارى از آلودكى باكتريايى مىشود اما با تغذيه از كياه آلودهاى كه روى آن مستقر است، مجدداً سريعاً آلوده مىشود. در ارويا، ممانعت از ورود ناقلين جديد و بهخصوص حشره Homalodisca vitripennis، از مهمترين اولويتهاى بازرسى مواد كياهى وارداتى است. اين حشره كه از ناقلين اصلى X. fastidiosa در آمريكا است، دامنه ميزبانى بسيار وسيعى دارد و مىتواند بهراحتى با شرايط اقليمى ارويا، آسيا و آفريقا سازكار شود.

ه-ץ- حذف گياهان آلوده: در كانون آلودَى و محدوده ييرامون آن، بايد كليه گياهان ميزبان (اعم از آلوده، سالم، آلودگىهاى ينهان) را از ريشه خارج و سوزاند. شعاع اين محدوده در انگلستان با توجه به طول يرواز 
زنجركها . 1 متر تعريف شده است. همجنين ييرامون كانون آلودگى منطقه حفاظت شدهاى ايجاد و جابجايى مواد كياهى در آن محدود يا ممنوع شده، سلامت گياهان ميزبان دائماً رصد و با حشرههاى ناقل و علفهاى هرز مبارزه مىشود. شعاع منطقه حفاظت شده در انغلستان • ا كيلومتر (از مرز كانون آلودگى) براى مدت ينج سال است. ه-r- مبارزه با حشره ناقل: اولين قدم در مبارزه با حشره ناقل، سمياشى در كانون آلودگى و كمربند حفاظتى يِيرامون آن است. شعاع اين محدود بر اساس طول يرواز حشره ناقل تعيين مىشود. يس از سمياشى لازم است ميزبانان آلوده نيز حذف شوند تا حشرههايى كه از اطراف به منطقه آلوده وارد مىشوند، آلوده نشوند. حذف گیاه آلوده قبل از سمياشى ممكن است موجب مهاجرت حشرههاى ناقل آلوده به مناطق ياك و

$$
\text { كسترش بيمارى شود. }
$$

ه-F- درمان كياهان آلوده: محلولياشى با آنتىبيوتيك تتراسيكلين קيشرفت اين بيمارى را متوقف و شدت نشانهها را كم مى كند. مثلاً محلولياشى تتراسيكلين ( • و و • • إيىيىام) موقتاً نشانهاى بيرس را در انكور كَلدانى متوقف مى كند؛ اما استفاده از آنتىبيوتيك خطرات زيستمحيطى دارد، علاوه بر اينكه بهبود قطعى نمى دهد و يس از قطع مصرف، بيمارى مجدداً تشديد مىشود. تيمار حرارت درمانى در دماى •ه درجه سانتى گراد به مدت • r دقيقه يا لها درجه سانتى گراد بهمدت r ساعت، باكترى X. fastidiosa را از بين مىبرد و مىتواند براى سالمسازى زرم پِلاسم بهكاربرده شود ( Goheen et al. 1973$).$ ه-ه- برودت زمستان: اين باكترى درون گَياه زمستان گذرانى مى كند و به سرما حساس است. از اين رو دماى زمستان عاملى كليدى در بقا و انتقال آن به سال آتى است. در بيمارى ييرس انكور، هر جه دماى زمستان براى مدت طولانىترى زير ه درجه سانتى

.( Henenberger et al. 2004)

ه-4- حفاظت تقاطعى: بيمارى ييرس انكور با استفاده از سوشهاى غيرمتخاصم مهار شده است. ه- ك- كاشت ارقام مقاوم: در برخى گياهان ميزبان ممكن است سطوح مقاومت برخى ارقام بهطور Carvalhais, معنى مارى بالاتر باشد. بهعنوان مثال، كليه ارقام ليموشيرين حساس، اكثر ارقام نارنگى (بهجز 
مقاوم و كليه ارقام ليموترش و يوملو مقاوم به زردى ابلق مركبات هستند، اكثر انگورهاى ارويايى (Wiking (V. labrusa L.) و هيبريدهاى فرانسه-آمريكا به بيرس انكور حساس بوده و (Vitis vinifera L.) مىميرند در حالى كه گَونهاى بومى آمريكاى جنوب شرقى مقاوماند و پس از شيوع پِيرس در ايالات متحده

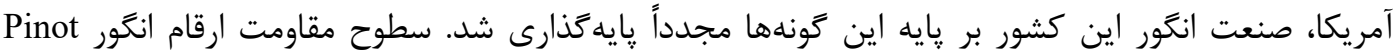
نسبت به Pinot sirah, Chenin blanc, Sylvaner, Flora همه ارقام قديمى ايتاليا مانند Salentina, Ogliarola, Cellina di Nardò, Frantoio, Coratina حساساند و ظاهراً رقم Leccino حساسيت كمترى دارد (Saponar et al. 2016).

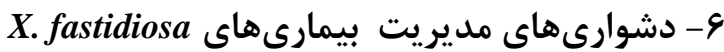

مبارزه با Jastidiosa. fanse and Obradovic 2010 دلايل زير يِيجيده و دشوار است (Jans). צ-1- تعدد ميزبان: تاكنون دامنه وسيعى از گياهان جوبى و علفى بهعنوان ميزبان شناخته شدهاند. بسيارى از گونههاى علفهاى هرز، درخت و درختجههاى زينتى و وحشى ميزبانان نهفته اين باكترى هستند و بسيارى از ميزبانان نهفته هنوز ناشناخته هستند.

X. fastidiosa إف- ايش روزافزون دامنه ميزبانى عامل بيمارى: زيركونهاى مختلف باكترى مىتواند از طريق نوتركيبى، توانايىهاى جديدى كسب و گَونهاى گياهى جديدى را آلوده كنند. بهعنوان مثال، سرايت سندروم زوال سريع زيتون به گَونهايى مانند گيلاس، بادام و آلو بسيار محتمل است. צ-r- تعدد حشرههاى ناقل و شناسايى ناقلان جديد: كليه حشرههاى تغذيهكننده از آوند جوبى يتانسيل انتقال اين بيمارى را دارند و اخيراً حشرههاى تغذيهكننده از آوند آبكش نيز به اين ليست افزوده شدهاند.

צ- \&- انتشار جغرافيايى: منشأ احتمالى X. fastidiosa قاره آمريكا بوده كه از آنجا به آسيا و ارويا منتشر شده است. نحوه اين انتشار معلوم نيست اما در جندين مورد، آلودگى در گياه قهوه صادر شده از آمريكاى جنوبى به ارويا مشاهده شده است. در حال حاضر مناطق اصلى انتشار آن شامل ارويا: ايتاليا و فرانسه، آمريكاى شمالى: كانادا، مكزيك، ايالات متحده آمريكا، آمريكاى جنوبى: آرزانتين، برزيل، كاستاريكا، ياراگوئه و ونزوئلا 
است. در قاره آسيا، ايران بعد از تايوان، دومين كشورى است كه اين باكترى را گزارش كرده است و گزارشى نيز از وقوع آلودكى در هند آمده است. در ايران آلودگى در انكَور (استانهاى جهارمحال و بختيارى، خراسان رضوى، قزوين، اصفهان، همدان، البرز) و بادام (استانهاى جهارمحال و بختيارى، آذربايجان غربى، سمنان) بوده است (Amanifar et al. 2014). خسارت اقتصادى عمده اين بيمارى در مناطق گرمسيرى يا نيمه كرمسيرى است و در نواحى با دماى زير • ا درجه سانتى گراد خسارات محدودى در حد سوختگى برى ايجاد مى كند.



سندروم زوال سريع زيتون براى اولين بار در سال rا • ب در درختان در حال زوال زيتون جنوب ايتاليا مشاهده شد. بررسىهاى اوليه نشان داد كه گرجه اين درختان به جندين گونه از قارجهاى بيمارىزا و آفت جوب خوار .Zeuzera sp. آلوده بودند، اما عامل اصلى زوال آنها X. fastidiosa subsp. pauca و منشأ احتمالى آلودگى گياهان وارداتى از كاستاريكا بوده است (Estokstad 2015). سرعت انتشار بسيار بالا بود به گونهاى كه

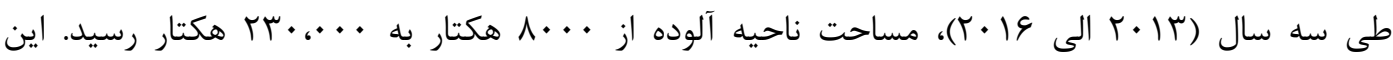
سندروم اكنون در جنوب ايتاليا همهگير شده و حداقل · · هزار هكتار از باغهاى زيتون را آلوده و بيش از يك ميليون درخت را خشكانده است.

V-ا-دامنه ميزبانى بيماركر: بر اساس نتايج بررسىهاى اوليه، علاوه بر زيتون، خرزهره و بادام نيز به X. fastidiosa subsp. pauca

(Martelli 2015)

V-V-V نشانه هاى سندروم زوال سريع زيتون: درختان زيتون در هر سنى از نهال تا درختان • • ساله به اين بيمارى حساس هستند. نشانهاى سندروم با سوختگى برى شاخههاى فوقانى درخت شروع و سيس به شاخههاى بيشترى گسترده مىشود، ميوهها مىريزند و سرشاخهها خشك مىشوند. كشاورزان براى احياى درخت، شاخههاى خشكيده را مىبرند اما شاخههاى تازه روئيده نيز بهسرعت خشك مىشوند. درختان آلوده ياجوشدهى زيادى دارند. سيس ريشه درخت مىميرد و بهدنبال آن پاجوشها و كل درخت مىخشكد. 
نشانهاى فوق معمولاً در همه درختان يك رديف ديده مىشود. بر اساس نتايج آزمايشهاى ييوند، دوره كمون (فاصله زمانى بين آلوده شدن تا بروز اولين نشانهها) حداقل هفت ماه است (2015 Martelli ). V-ץ- مديريت سندروم زوال سريع زيتون: بر اساس دستورالعمل كميسيون اتحاديه ارويا (تصميم

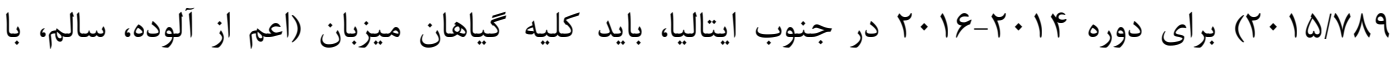
آلودكى ينهان) در فاصله . . 1 مترى از منطقه آلوده از ريشه خارج و سوزانده شوند كه با توجه به تعدد گونههاى مختلف گياهان ميزبان، ناحيهاى بى گياه (ناحيه سوخته، Dead zone) ايجاد مىشود. سيس در فاصله •r كيلومترى پيرامون ناحيه سوخته، كمربند بافرى (Buffer zone) ايجاد شود كه در آن، بهطور مدام سلامت كليه ميزبانان رصد شده، حشره ناقل توسط آفتش مديريت و با علفهاى هرز مبارزه مىشود. اسامى ميزبانان از وهو جنس در كاتالوكى در اختيار باغداران قرار داده شده است. با وجود تدابير فوق، ظاهراً حشرههاى ناقل از كمربند امنيتى عبور كرده و آلودگى را به مناطق شمالى ايتاليا منتقل كردهاند. بر اساس مدلهاى انتشار، پِيشبينى مىشود بهزودى محدوده وسيعى از ايتاليا آلوده شود و به يرتغال، اسيانيا، فرانسه، مونت نكرو، آلبانى، يونان، تركيه و سيس شمال افريقا و خاورميانه سرايت كند. آب و هواى مناطق مديترانهاى و مناطق گرم ارويا كه زمستانى مشابه جنوب آمريكا دارند، براى انتشار اين بيمارى مساعد است. همجنين افزايش جهانى دما و خشكسالى بر سرعت انتشار آن خواهد افزود. اين بيمارى اكنون در ليست بيمارىهاى قرنطينهاى ارويا است و مدت زمان قرنطينه آن دو سال منظور شده و برخى كشورهاى ارويايى از جمله فرانسه، واردات زيتون از جنوب ايتاليا را ممنوع كردهاند (Martelli 2015, Martelli et al. 2016 ).

\section{نتيجهَكيرى و بيشنههاد}

بيمارى سندروم زوال سريع زيتون كه در كشورهاى ارويايى حوزه درياى مديترانه شيوع دارد، بسيار حائز اهميت است و در نهايت به مرى درخت منتهى مىشود. بلهدليل سيستميك بودن ماهيت بيمارى و نبود سم مؤثر عليه آن، حذف ميزبانان آلوده تنها راه مديريت است كه با توجه به وسعت دامنه ميزبانى و نهان بودن بيمارى در بسيارى ميزبانها، اين اقدام بلمنزله حذف گَونهاى متعدد گياهى در كانون آلودگى و نظارت شديد بر سلامت آنها در اطراف كانون براى ساليان متمادى است. لذا ييشنهاد مىشود براى پيشخيرى، 


$$
\begin{aligned}
& \text { دقت زيادى در قرنطينه واردات كليه گياهان ميزبان و حشرات ناقل (بالغ، تخم، يوره) صورت بخيرد، واردات } \\
& \text { گياهان ميزبان از ايتاليا ممنوع و از ساير كشورهاى ارويايى و تركيه تنها در حد ضرورت انجام شود و اسامى } \\
& \text { ميزبانان و حشرههاى ناقل دائماً باهروز شده و تحت نظارت و پايش مداوم قرار داده شوند. }
\end{aligned}
$$

\section{References}

1. Amanifar N., Taghavi T., Izadpanah K. and Babbel G. 2014. Isolation and pathogenicity of Xylella fastidiosa from grapevine and almond in Iran. Phytopathologia Mediterranea $53: 318-327$

2. Denance N., Legendre B., Briand M., Olivier V., de Boisseson C., Poliakoff F. and Jacques M. A. 2017. Several subspecies and sequence types are associated with the emergence of Xylella fastidiosa in natural settings in France. Journal of Plant Pathology 66:1054-1064.

3. Estokstad E. 2015. Italy's olive under siege. Science 348:620.

4. Giampetruzzi A., Chiumenti M., Donvito G., Italiano A., Loconsole G., Boscia D., Gardidi C., Martelli G. P. and Saldarelli P. 2015. Draft genome sequence of the Xylella fastidiosa CoDiRO strain. Genome Announcements 3, 01538-14. Genome Announcements, 3:e0153814.

5. Goheen A. C., Nyland G. and Lowe S.K. 1973. Association of a rickettsia-like organism with Pierce's disease of grapevines and alfalfa dwarf and heat therapy of the disease in grapevines. Phytopathology 63:341-345

6. Henenberger T. S. M., Stevenson K. L., Britton K. O. and Chang C. J. 2004. Distribution of Xylella fastidiosa in sycamore associated with low temperature and host resistance. Plant Disease 88:951-958.

7. Hopkins D. L. and Purcell A. H. 2002. Xylella fastidiosa: cause of Pierce's disease of grapevine and other emerging diseases. Plant Disease 86:1056-1066

8. Hopkins D. L. 1989. Xylella fastidiosa: xylem-limited bacterial pathogen of plants. Annual Review of Phytopathology 27: 271-290

9. Janse J. D. and Obradovic A. 2010. Xylella fastidiosa: Its biology, diagnosis, control and risks. Journal of Plant Pathology 92:35- 48

10.Martelli G. P. 2015. The current status of the quick decline syndrome of olive in southern Italy. Phytoparasitica 44:1-10 
11.Martelli G. P., Bosica D., Porcelli F. and Saponari M. 2016. The olive quick decline syndrome in south-east Italy: a threatening phytosanitary emergency. European Journal of Plant Pathology 144:235-243

12.Nigro F., Boscia D., Antelmi I. and Ippolito A. 2013. Fungal species associated with a severe decline of olive in Souther Italy. Journal of Plant Pathology 95:668-678.

13. Rakitov R. A. 2004. Powdering of egg nests with brochosomes and related sexual dimorphism in leafhoppers (Hemiptera: Cicadellidae). Zoological Journal of the Linnaean Society 140:353-381.

14. Saponari M., Boscia D. and Altamura G. 2016. Pilot project on Xylalla fastidiosa uncertainties. EFSA Supporting Publications 13:1013.

15.Saponari M., Boscia D., Nigro F. and Martelli G. P. 2013. Identification of DNA sequences related to Xylella fastidiosa oleander, almond and olive trees exhibiting leaf scorch symptoms in Apulia (Southern Italy). Journal of Plant Pathology (online paper).

16. Severin H.H. 1949. Transmission of the virus of Pierce's disease by leafhoppers. Hilgardia 19:190-202 